\title{
Assessment of Trace Metals in Soils of North-Eastern Lubumbashi (Upper-Katanga Province, Democratic Republic of Congo)
}

Bamba Bukengu Muhaya ${ }^{1}$, Amakay Bukas ${ }^{1}$, François Toto Lubala ${ }^{2}$, Pierre Kambuli Kaseti ${ }^{2}$ and Joel Bacirheba Mugisho $^{2}$

1. Department of Chemistry, Faculty of Science, Lubumbashi University, Lubumbashi 1825, D.R. Congo

2. Department of Geology, Faculty of Science, Lubumbashi University, Lubumbashi 1825, D.R. Congo

\begin{abstract}
Concentrations of $\mathrm{Co}, \mathrm{Cu}, \mathrm{Cr}, \mathrm{Fe}, \mathrm{Pb}$ and $\mathrm{Zn}$ were investigated in samples of five types of soils: Dembo soil $\mathrm{SDC}$, red clay soil SAR, red clay soil with black spots SAK, lateritic soil SLS and garbage dump soil SNB from the North-eastern Lubumbashi city in the Democratic Republic of Congo from February to July 2011, corresponding to three months (February-April) of rainy season and three months (May-July) of dry season. Of the five soil types, SDC and SNB had higher $\mathrm{Co}, \mathrm{Cr}, \mathrm{Fe}$ and $\mathrm{Pb}$ concentrations at A and B horizons than the other soils. In those two soil types, respective mean concentrations of Co were $143 \mathrm{mg} / \mathrm{kg}$ and $485 \mathrm{mg} / \mathrm{kg}$; those of $\mathrm{Cr}$ were $105 \mathrm{mg} / \mathrm{kg}$ and $124 \mathrm{mg} / \mathrm{kg}$, those of Fe were $42,420 \mathrm{mg} / \mathrm{kg}$ and $41,327 \mathrm{mg} / \mathrm{kg}$, and those of Pb were $21 \mathrm{mg} / \mathrm{kg}$ and $1,837 \mathrm{mg} / \mathrm{kg}$. Both SDC and SNB soils had also high organic matter content varying from $4.04 \%$ to $13.36 \%$ and from $5.8 \%$ to $11.9 \%$, respectively. Their $\mathrm{pH}$ values ranged from 6.9 to 7.8 and from 7.3 to 8.0 , respectively.
\end{abstract}

Key words: Trace metals, soils, organic matter, $\mathrm{pH}$, Lubumbashi.

\section{Introduction}

For a longtime, studies on trace metal contamination of soils have been neglected on the contrary to studies on air and water contamination. It is only at the end of the eighties that industrialized countries, through their ministries of Environment, launched an inventory of contaminated sites in order to identify and rehabilitate them [1].

In the Democratic Republic of Congo (DRC), mining activities and other human activities generate diverse types of waste which unfortunately are not given particular considerations with respect to soil. Among the mining waste components, the problem of trace metals in soils is quite singular. It is linked to the contamination specificity, often multi-element, and to the chemical characteristics of the pollutant-soil system.

Corresponding author: Bamba Bukengu Muhaya, associate professor, Ph.D., main research field: assessing and mapping environmental and health impacts of abandoned and active mining activities and its neighborhood.
The presence of trace metals in soils is particularly problematic due to their toxicity and their non-biodegradability with respect to a part of organic pollutants. Although some trace metals are essential to life at low levels (e.g. $\mathrm{Zn}$ and $\mathrm{Co}$ ), they become toxic in high content. Other metals such as $\mathrm{Pb}, \mathrm{Cd}$ and $\mathrm{Hg}$ are very toxic even in very small quantities.

The Lubumbashi city has active and disused sites including active mines, ore processing plants, tailings, dumps and industrial wastelands possibly able to generate trace metal contamination of soils in urban zones. That contamination is likely to affect soils, surface water [2] and groundwater [3], endangering the supply of drinking water.

The objective of this study is to assess the degree of soil contamination by trace metals, such as $\mathrm{Cu}, \mathrm{Co}, \mathrm{Fe}$, $\mathrm{Cr}, \mathrm{Pb}$ and $\mathrm{Zn}$, in the top soils up to $30 \mathrm{~cm}$ in depth, with the aim to highlight the impact of mining exploitation and processing in the North-eastern part of Lubumbashi city. 


\section{Material and Methods}

\subsection{Site Description}

Lubumbashi, the capital city of the Katanga province is located at $27^{\circ} 29^{\prime}$ of latitude south and $11^{\circ} 41^{\prime}$ of longitude east in the South-east of the Democratic Republic of Congo, less than $50 \mathrm{~km}$ from the DRC-Zambia border (Fig. 1).

The annual mean temperature is $20{ }^{\circ} \mathrm{C}$ with a minimum of $8{ }^{\circ} \mathrm{C}$ and a maximum of $32{ }^{\circ} \mathrm{C}$. The rainy season lasts 5 to 6 months, from November to March and the dry season 5 months from May to September. April and October constitute transition periods between the two seasons.

The city is located at the inter-tropical convergence zone under the influence of South-east trend winds coming from the Indian Ocean with dominant winds blowing from East to South-east during most parts of the year, mainly in dry season.

The study site covers the North-eastern suburbs of Lubumbashi namely Annexe, Kampemba and Ruashi
(Fig. 1). This area corresponds to a new industrial zone occupied by mining companies such as Congo Dongfang Mining, Ruashi Mining and Chemaf. The soil is in large partly clay containing some gravel, lateritic and hydromorphic pockets (valley soils called Dembo, seasonally flooded savanna rich in organic matter). Water supply by REGIDESO (the Congolese water supply company) is poorly developed in that part of the city. Thus river (surface water) and water wells (groundwater) constitute the main water source for the local population.

\subsection{Sampling Campaign}

The sampling of topsoil was carried out once a month during six months from the three first layers excluding the organic rich layer: These are A layer (0-10 cm of depth), B layer (10-20 cm of depth) and C layer (20-30 cm of depth) from February to July 2011. This period covers the wet season (February-April) and the dry season (May-July). Soil cores in the specified layers were extracted using a hand drill.
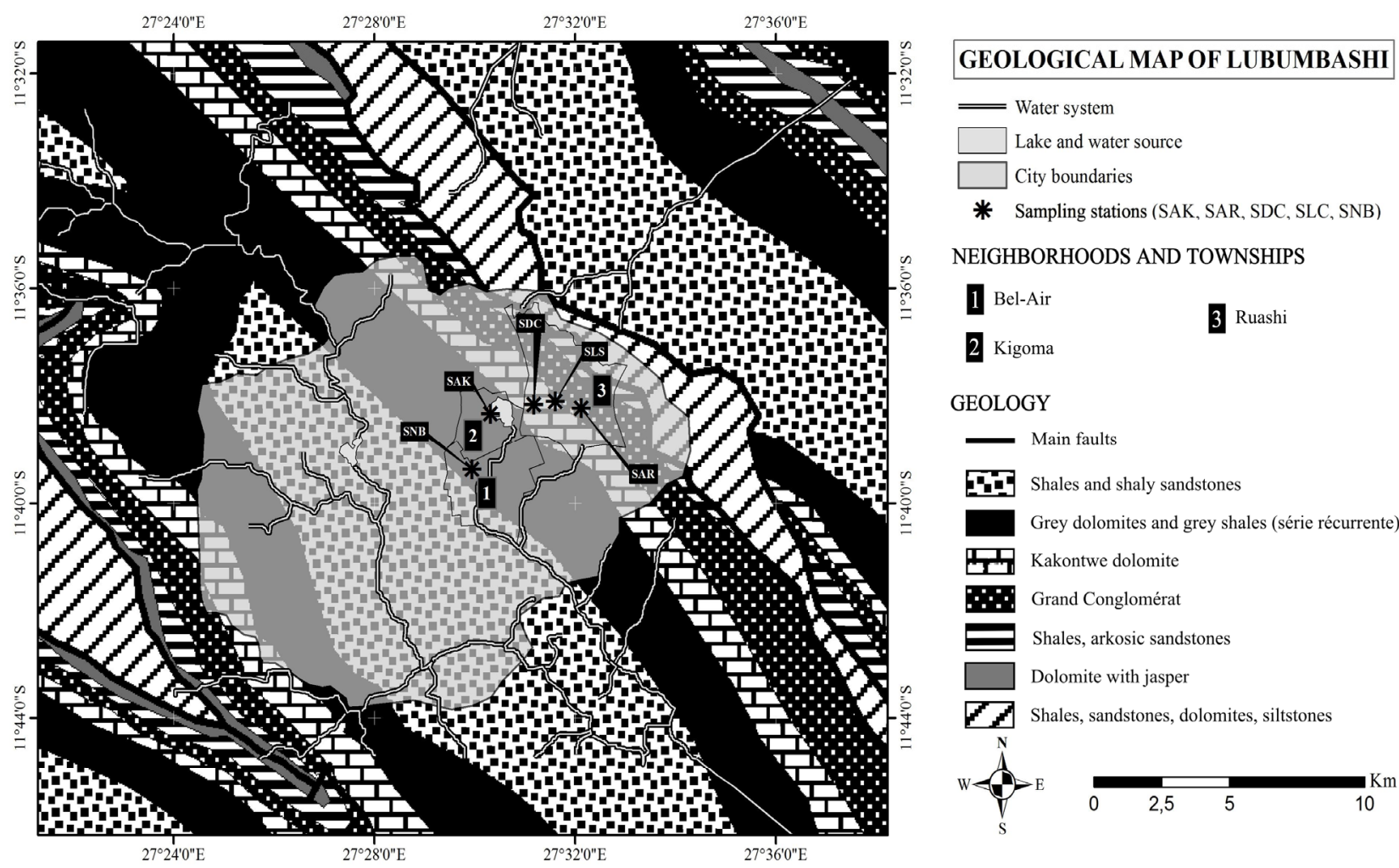

NEIGHBORHOODS AND TOWNSHIPS

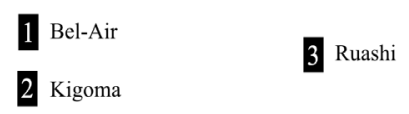

GEOLOGY

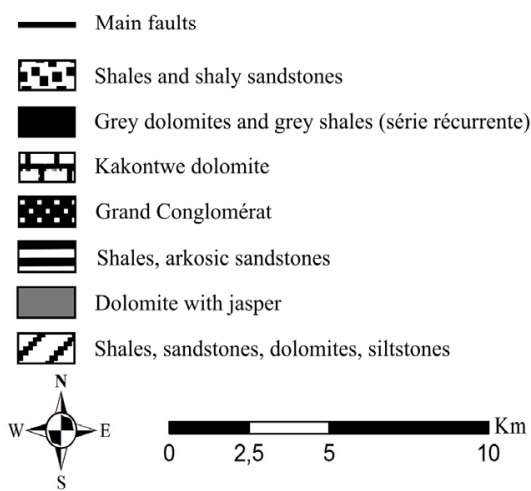

Fig. 1 Map of Lubumbashi city showing the soil sampling sites. 
The sampling sites (Fig. 1) were chosen randomly but according to wind direction and land slope with holes or cavities likely to offer sedimentation and the average sampling density is around 20 samples $/ \mathrm{km}^{2}$, which is suitable for a detailed phase of survey.

Together with the determination of metallic elements, the determination of total organic carbon (TOC), total carbonate carbon (TCC) and the determination of $\mathrm{pH}(\mathrm{KCl})$ of soil water leachate was conducted.

\subsection{Analytical Methods}

For trace metals, sample analyses were carried out at the Robinson International in Africa laboratory in Lubumbashi using Aqua Regia ICP-AES method.

$\mathrm{pH}$-soil measurements were carried out at the Agro Food Research Center (CRAA) in Lubumbashi, whereas the effective acidity or active acidity ( $\mathrm{pH}$-water) were measured using a Mettler $\mathrm{pH}$-meter.

Organic carbon or organic matter was analyzed in the laboratory of the Chemistry Department, Faculty of Science, Lubumbashi University by the method of weight loss on ignition.

\section{Results and Discussion}

Mean levels of chemical parameters in function of soil depth during the six months of the study are presented in Tables 1 and 2.

In SAR soil the concentration zones of various analyzed chemical parameters are distinguished. Thus at 10-cm depth, a peak of organic matter is noticed, and at the same depth the concentrations of the six studied heavy metals were highest. Numerous authors [4-9] have demonstrated that organic matter generally constituted an efficient substratum for heavy metal fixation. Nevertheless $\mathrm{Pb}$ distribution between 0 and $10 \mathrm{~cm}$ results in the reduction of the toxicity risk linked to the metal during the wet season while the important organic matter content noted in the same soil at $30 \mathrm{~cm}$ during the dry season coincided with high levels of $\mathrm{Cu}, \mathrm{Fe}$ and $\mathrm{Cr}$ but not of $\mathrm{Co}, \mathrm{Pb}$ and $\mathrm{Zn}$. However, the absence of concentration gradient between the first two layers decreases the risk that may present $\mathrm{Pb}$ and $\mathrm{Zn}$ during the considered period. The $\mathrm{pH}$ range of 5.9-6.4 noted during this study indicates that the SAR soil is acid but that acidity appears in two degrees: acid at $\mathrm{pH} 5.5$ to 6.0 and less acid at $\mathrm{pH} 6.0$ to 6.5 [10]. The SLS soil has a high organic matter percentage at 30-centimeter depth during the wet season and the levels of trace metals such as $\mathrm{Cu}, \mathrm{Co}$ and $\mathrm{Zn}$ are as well high there, on the

Table 1 Mean values of different parameters in soils of North-eastern Lubumbashi during the period of February, March and April 2011 (rainy season).

\begin{tabular}{llllllllll}
\hline \multirow{2}{*}{ Soil sample code } & Soil stratum & \multicolumn{3}{c}{$\begin{array}{c}\text { Physicochemical } \\
\text { parameters }\end{array}$} & \multicolumn{5}{c}{ Trace metal concentration (ppm dry wt.) } \\
\cline { 3 - 10 } & $(\mathrm{cm})$ & $\mathrm{pH}$ & $\mathrm{OM}(\%)$ & $\mathrm{Cu}$ & $\mathrm{Co}$ & $\mathrm{Fe}$ & $\mathrm{Cr}$ & $\mathrm{Pb}$ & $\mathrm{Zn}$ \\
\hline SAR & $0-10$ & 6.2 & 5.03 & 217 & 227 & 38,687 & 67 & 6.7 & 130 \\
& $10-20$ & 6.0 & 4.01 & 143 & 187 & 36,687 & 30 & 6.7 & 120 \\
& $20-30$ & 5.9 & 4.44 & 157 & 133 & 34,157 & 47 & 3.3 & 63 \\
SLS & $0-10$ & 4.6 & 5.53 & 120 & 193 & 91,960 & 103 & 3.3 & 87 \\
& $10-20$ & 4.8 & 5.37 & 97 & 263 & 100,540 & 150 & 3.3 & 30 \\
SDC & $20-30$ & 4.6 & 6.16 & 150 & 300 & 88,483 & 97 & 3.3 & 110 \\
& $0-10$ & 6.0 & 7.07 & 473 & 133 & 130,377 & 13 & 16.7 & 140 \\
& $10-20$ & 5.9 & 8.97 & 547 & 177 & 29,213 & 10 & 0 & 147 \\
SNB & $20-30$ & 6.0 & 7.15 & 543 & 100 & 17,531 & 20 & 10 & 113 \\
& $0-10$ & 7.6 & 7.59 & 2,443 & 547 & 34,390 & 90 & 547 & 910 \\
SAK & $10-20$ & 7.6 & 9.54 & 1,880 & 673 & 48,713 & 127 & 710 & 970 \\
& $20-30$ & 7.6 & 9.39 & 2,430 & 390 & 49,907 & 120 & 707 & 1167 \\
& $0-10$ & 4.9 & 6.75 & 203 & 140 & 41,833 & 10 & 6.7 & 63 \\
\end{tabular}


Table 2 Mean values of different parameters in soils of North-eastern Lubumbashi during the period of May, June and July 2011 (dry season).

\begin{tabular}{|c|c|c|c|c|c|c|c|c|c|}
\hline \multirow{2}{*}{$\begin{array}{l}\text { Soil sample } \\
\text { code }\end{array}$} & \multirow{2}{*}{$\begin{array}{l}\text { Soil stratum } \\
(\mathrm{cm})\end{array}$} & \multicolumn{2}{|c|}{$\begin{array}{c}\text { Physicochemical } \\
\text { parameters }\end{array}$} & \multicolumn{6}{|c|}{ Trace metal concentration (ppm dry wt.) } \\
\hline & & $\overline{\mathrm{pH}}$ & OM (\%) & $\mathrm{Cu}$ & Co & $\mathrm{Fe}$ & $\mathrm{Cr}$ & $\mathrm{Pb}$ & $\mathrm{Zn}$ \\
\hline \multirow{3}{*}{ SAR } & $0-10$ & 6.3 & 4.2 & 210 & 175 & 45,650 & 70 & 20 & 90 \\
\hline & $10-20$ & 6.4 & 4.9 & 180 & 140 & 46,550 & 65 & 20 & 90 \\
\hline & $20-30$ & 6.4 & 5.2 & 260 & 130 & 48,280 & 95 & 10 & 85 \\
\hline \multirow{3}{*}{ SLS } & $0-10$ & 4.4 & 6.5 & 140 & 105 & 97,400 & 225 & 10 & 53 \\
\hline & $10-20$ & 5.7 & 5.2 & 143 & 100 & 97,950 & 225 & 10 & 75 \\
\hline & $20-30$ & 5.5 & 5.2 & 125 & 105 & 92,100 & 175 & 10 & 95 \\
\hline \multirow{3}{*}{ SDC } & $0-10$ & 7.6 & 4.8 & 375 & 123 & 23,650 & 75 & 10 & 60 \\
\hline & $10-20$ & 7.1 & 5.9 & 360 & 220 & 26,400 & 403 & 70 & 165 \\
\hline & $20-30$ & 6.9 & 6.3 & 410 & 105 & 27,350 & 107 & 20 & 100 \\
\hline \multirow{3}{*}{ SNB } & $0-10$ & 7.4 & 7.0 & 1,837 & 465 & 36,200 & 145 & 2,900 & 1,180 \\
\hline & $10-20$ & 7.5 & 7.2 & 1,365 & 615 & 33,750 & 180 & 2,705 & 550 \\
\hline & $20-30$ & 7.5 & 8.7 & 1,695 & 220 & 45,000 & 85 & 3,455 & 860 \\
\hline \multirow{3}{*}{ SAK } & $0-10$ & 5.1 & 7.1 & 325 & 125 & 43,450 & 120 & 20 & 220 \\
\hline & $10-20$ & 5.1 & 6.0 & 268 & 70 & 44,550 & 117 & 10 & 68 \\
\hline & $20-30$ & 5.1 & 6.8 & 210 & 240 & 44,500 & 100 & 10 & 90 \\
\hline
\end{tabular}

contrary of $\mathrm{Fe}$ and $\mathrm{Pb}$ levels which do not vary in all three layers of the studied soils, thus reducing the danger likely to be generated by those metals.

During the period of May, June and July 2011 (dry season), the variation of organic matter content of the SLS soil layers of $0-10 \mathrm{~cm}(6.49 \%), 10-20 \mathrm{~cm}(5.19 \%)$ and $20-30 \mathrm{~cm}(5.15 \%)$ does not correspond to the concentration variation of $\mathrm{Cu}(140 \mathrm{mg} / \mathrm{kg}, 143 \mathrm{mg} / \mathrm{kg}$ and $125 \mathrm{mg} / \mathrm{kg}$, respectively), Fe $(97,400 \mathrm{mg} / \mathrm{kg}$, 97,950 $\mathrm{mg} / \mathrm{kg}, \quad 92,100 \mathrm{mg} / \mathrm{kg}$, respectively), $\mathrm{Zn}$ $(53 \mathrm{mg} / \mathrm{kg}, 75 \mathrm{mg} / \mathrm{kg}$ and $95 \mathrm{mg} / \mathrm{kg}$, respectively), Co $\quad(105 \mathrm{mg} / \mathrm{kg}, \quad 100 \mathrm{mg} / \mathrm{kg}$ and $105 \mathrm{mg} / \mathrm{kg}$, respectively), $\mathrm{Cr}(225 \mathrm{mg} / \mathrm{kg}, 225 \mathrm{mg} / \mathrm{kg}$ and 175 $\mathrm{mg} / \mathrm{kg}$, respectively) and $\mathrm{Pb}(10 \mathrm{mg} / \mathrm{kg}, 10 \mathrm{mg} / \mathrm{kg}$ and $10 \mathrm{mg} / \mathrm{kg}$, respectively) in those respective depth layers of $0-10 \mathrm{~cm}, 10-20 \mathrm{~cm}$ and $20-30 \mathrm{~cm}$. The invariability of the respective concentrations of $\mathrm{Cr}(225 \mathrm{mg} / \mathrm{kg}$ and $225 \mathrm{mg} / \mathrm{kg})$ and $\mathrm{Pb}(10 \mathrm{mg} / \mathrm{kg}$ and $10 \mathrm{mg} / \mathrm{kg}$ ) in the first two layers limits the damage due to those metals. The $\mathrm{pH}$ range of 4.4-5.7 indicates that the SLS soil is very acid [10]. During the period of February, March and April 2011 (wet season), the SDC soil recorded substantial organic matter content $(8.97 \%)$ at $10-20 \mathrm{~cm}$ depth and high levels of $\mathrm{Co}(177 \mathrm{mg} / \mathrm{kg}), \mathrm{Cu}(547 \mathrm{mg} / \mathrm{kg})$ and $\mathrm{Zn}$
$(147 \mathrm{mg} / \mathrm{kg})$. The $\mathrm{pH}$ values in the interval of 5.9 to 6.0 clearly indicated that the soil was acid at that period. This is in agreement with Mench and Baize [11] who reported that the half of ploughed soil layers in Lubumbashi is acidic. But the same SDC soil presented high organic matter content $(6.29 \%)$ at 20-30 cm depth during the period of May to July 2011 (dry season) and high concentrations of $\mathrm{Cu}(410$ $\mathrm{mg} / \mathrm{kg})$ and $\mathrm{Fe}(27,350 \mathrm{mg} / \mathrm{kg})$. During the same period, $\mathrm{pH}$ values of the first two layers $(0-10 \mathrm{~cm}$ and $20-20 \mathrm{~cm}$ ) of the SDC soil were respectively 7.6 and 7.12 , that is to say values of alkaline $\mathrm{pH}$ and the third layer $(20-30 \mathrm{~cm}$ depth) had a $\mathrm{pH}(6.89)$ close to neutral.

In the SNB soil, the season change did not influence the $\mathrm{pH}$ values seriously. Thus, during the current study period (February-July 2011), the pH remained alkaline with mean values ranging from 7.4 to 7.64 . The highest organic matter content $(9.54 \%)$ at $10-20 \mathrm{~cm}$ depth during the wet season coincides with the high levels of Co $(673 \mathrm{mg} / \mathrm{kg}), \mathrm{Cu}(1,880 \mathrm{mg} / \mathrm{kg})$ and $\mathrm{Pb}(710 \mathrm{mg} / \mathrm{kg})$, and the abundance of organic matter $(8.65 \%)$ at $20-30 \mathrm{~cm}$ depth during the period of May to July 2011 (dry season) also implies high concentrations of $\mathrm{Pb}(3,455 \mathrm{mg} / \mathrm{kg})$ and $\mathrm{Fe}(45,000$ 
$\mathrm{mg} / \mathrm{kg})$, and low levels of $\mathrm{Cu}(1,695 \mathrm{mg} / \mathrm{kg})$ and $\mathrm{Co}$ $(220 \mathrm{mg} / \mathrm{kg})$ in that soil layer.

The high percentage of organic matter $(7.11 \%)$ at 10-20 cm depth of the SAK soil corresponded to the high levels of Co $(150 \mathrm{mg} / \mathrm{kg}), \mathrm{Fe}(52,493 \mathrm{mg} / \mathrm{kg})$ and to low level of $\mathrm{Cr}(13 \mathrm{mg} / \mathrm{kg})$ during the period of February to April 2011 (wet season). The constancy of Zn low concentration $(63 \mathrm{mg} / \mathrm{kg})$ in all three layers reduces the risk linked to that metal. During the period of May to July 2011 (dry season), organic matter became substantial $(7.14 \%)$ in that SAK soil at $0-10$ $\mathrm{cm}$ depth, that correlated with the high concentrations of $\mathrm{Cu}(325 \mathrm{mg} / \mathrm{kg}), \mathrm{Cr}(120 \mathrm{mg} / \mathrm{kg})$ and $\mathrm{Pb}(20$ $\mathrm{mg} / \mathrm{kg}$ ).

The range of $\mathrm{pH}(4.8-5.1)$ noted in the SAK soil from February to July 2011 proves that soil was very acid. The $\mathrm{pH}$ and organic matter are among the factors which favor heavy metal retention in soils and indicate meanwhile the quality of soils $[9,10,12]$. Organic matter rich soils play, for the same reasons as those presenting alkaline $\mathrm{pH}$, the role of trapping heavy metals [4-6, 9]. Thus the latter soils are comparable to a delayed-action bomb since only little $\mathrm{pH}$ decrease is enough to mobilize those metals in soil solution, which makes their toxicity risk to increase. Indeed metals such as $\mathrm{Zn}, \mathrm{Pb}, \mathrm{Cu}$, $\mathrm{Co}$ and $\mathrm{Fe}$ are less mobile than $\mathrm{Cr}$ [8]. Several studies indicate that those metals migrate less in depth in soils except in particular/specific drainage conditions or in an acid medium. However, there is a $\mathrm{pH}$ under which metals are suddenly relegated. This $\mathrm{pH}$ is different according to the considered metal: $\mathrm{pH} 4$ for $\mathrm{Pb}, \mathrm{pH} 5$ for $\mathrm{Cu}, \mathrm{pH}$ 5.5 for $\mathrm{Zn}, \mathrm{pH} 7.4$ for $\mathrm{Co}, \mathrm{pH} 4$ for $\mathrm{Cr}$ and $\mathrm{pH}-2.5$ for Fe. Thus, soil $\mathrm{pH}$ has a very strong influence on the soil capacity not only to retain pollutants but also to relegate them, which would explain the fluctuations of trace metal concentrations noted in different soil layers during the present study.

The mean $\mathrm{pH}$ values observed in the SAR, SLS, SDC and SAK soils (Table 1) during the period of February to April 2011 (wet season) indicate that the rain waters caused a $\mathrm{pH}$ decrease in those soils. That $\mathrm{pH}$ decrease was more significant in the SDC soil while on the contrary the mean $\mathrm{pH}$ values of the SNB soil were noticeably increased during the rainy season. The mean values of soil organic matter content during that period show an organic matter decrease in the SAR, SLS and SAK soils and a significant organic matter increase in the SDC and SNB soils. For the same reasons as the alkaline $\mathrm{pH}$, organic matter reflects the degree of soil contamination by trace metals [13]. So from the results presented in Tables 1 and 2, it can be noticed that trace metals such as $\mathrm{Cu}$, $\mathrm{Co}, \mathrm{Cr}, \mathrm{Zn}, \mathrm{Pb}$ were accumulated in the SDC and SNB soils SDC with much higher concentrations in those soils compared with the other soil types.

The SDC and SNB soils were rich in organic matter as compared with the other studied soil types and the highest values were noted in the $20-30 \mathrm{~cm}$ depth layer during the rainy season on the contrary of the A layer (0-10 cm depth) where low organic matter contents were registered. Thus, during the dry season the SNB soil was the only soil type to present a substantial organic matter value in the $\mathrm{C}(20-30 \mathrm{~cm}$ depth) layer. The recorded $\mathrm{pH}$ values in the SNB and SDC soils let see that those soils were alkaline or a bit alkaline in accordance with the respective $\mathrm{C}$ and $\mathrm{A}$ horizons and the respective periods (during the rainy and dry seasons for the SNB soil and during the dry season for the SDC soil).

The mean trace metal concentrations in the SDC and SNB soils for the whole period of the present study exceed the maximum concentrations fixed by Switzerland in agricultural soils and the concentrations decreed by the European Union and the Organization for Economic Cooperation and Development (OECD) countries [14] which are 75 ppm for $\mathrm{Cr}, 25 \mathrm{ppm}$ for $\mathrm{Co}, 50 \mathrm{ppm}$ for $\mathrm{Cu}, 50 \mathrm{ppm}$ for $\mathrm{Pb}$ and $200 \mathrm{ppm}$ for $\mathrm{Zn}$. Those metals are pollutants and their maximal concentrations in the $\mathrm{A}$ (0-10 $\mathrm{cm}$ depth) or B (10-20 $\mathrm{cm}$ depth) horizon were higher than the Swiss guideline value, except for $\mathrm{Cr}$ 
and $\mathrm{Pb}$ in the SDC soil which did not exceed the guideline values during the rainy season and for $\mathrm{Zn}$ in the same soil during the wet and dry seasons.

The analysis of both Figs. 2 and 3 by the vertical comparison method shows that the studied trace metals presented a concentration gradient which moved either towards the A layer or towards the $\mathrm{B}$ layer with a fluctuation which decreased in the A layer all along the period of February to April 2011 (rainy season). That was the case of $\mathrm{Cu}, \mathrm{Co}, \mathrm{Fe}, \mathrm{Zn}$ and $\mathrm{Pb}$ in the $\mathrm{SDC}$ soil and $\mathrm{Cu}, \mathrm{Co}, \mathrm{Cr}$ and $\mathrm{Pb}$ in the SNB soil.

Mean trace metal concentrations had higher values in the A and B layers of both SDC and SNB soils rich in organic matter during the rainy season. Those soils thus benefited from $\mathrm{Cu}, \mathrm{Co}, \mathrm{Fe}, \mathrm{Cr}, \mathrm{Pb}$ and $\mathrm{Zn}$ contribution through anthropogenic activities, more precisely through ore treatment hence the relative accumulation of those metals either in the A layer or in the B layer. That can be explained by the particular conditions of drainage and organic matter content of those soils. On the other hand, $\mathrm{Cr}$ in the SDC soil and $\mathrm{Zn}$ as well as $\mathrm{Fe}$ in the SNB soil were found much more in the $\mathrm{C}$ layer, suggesting their natural origin.
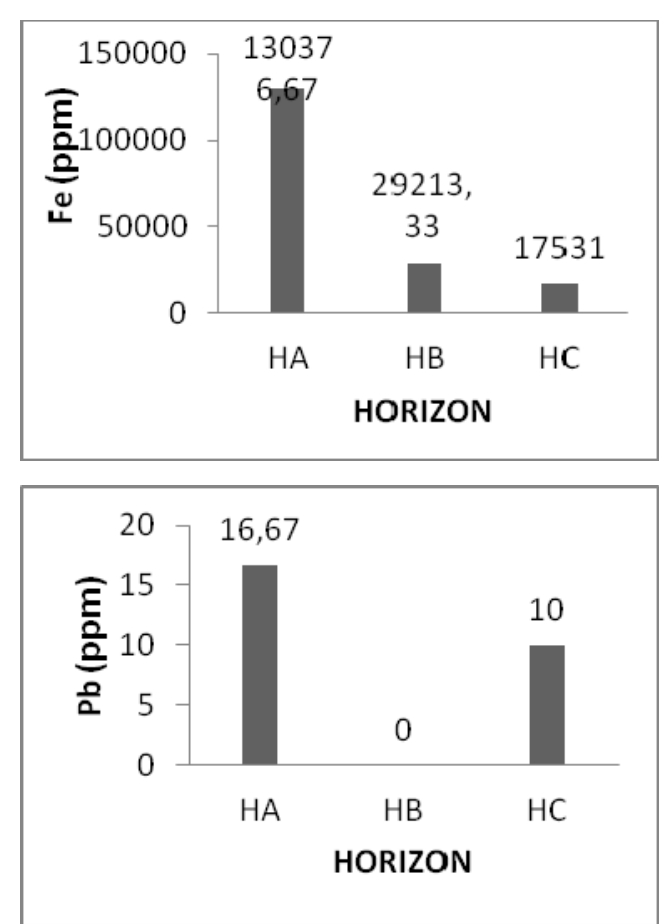

Fig. 2 Evolution of different parameter mean values in the SDC soil of North-eastern Lubumbashi during the period of February, March and April 2011 (rainy season).
The correlation between the vertical variation of the organic matter content and that of $\mathrm{Cu}$ concentration in the SDC soil as well as $\mathrm{Pb}$ and $\mathrm{Cr}$ in the SNB soil sufficiently showed that those metals were from anthropic origin [1]. On the contrary the correlation between the vertical variation of $\mathrm{Zn}$ and $\mathrm{Fe}$ concentrations in the SNB soil suggests that $\mathrm{Zn}$ was from natural origin.

During the period of May to July 2011 (dry season), the $\mathrm{pH}$ values of the SDC soil decreased from the A layer to the $\mathrm{C}$ layer, and conversely organic matter content and $\mathrm{Fe}$ level increased from the A layer to the C layer (Fig. 4). As for the other metals analyzed in that soil, their levels showed no precise tendency compared with $\mathrm{pH}$ or organic matter evolution in the three layers of that soil during the concerned period. In the SNB soil, the $\mathrm{pH}$ and organic matter content values increased from the A layer to the $\mathrm{C}$ layer during the period of May to July 2011 but the concentration values of the analyzed trace metals in the three layers of that soil did not show any precise tendency/trend with comparison to $\mathrm{pH}$ and organic matter evolution (Fig. 5).
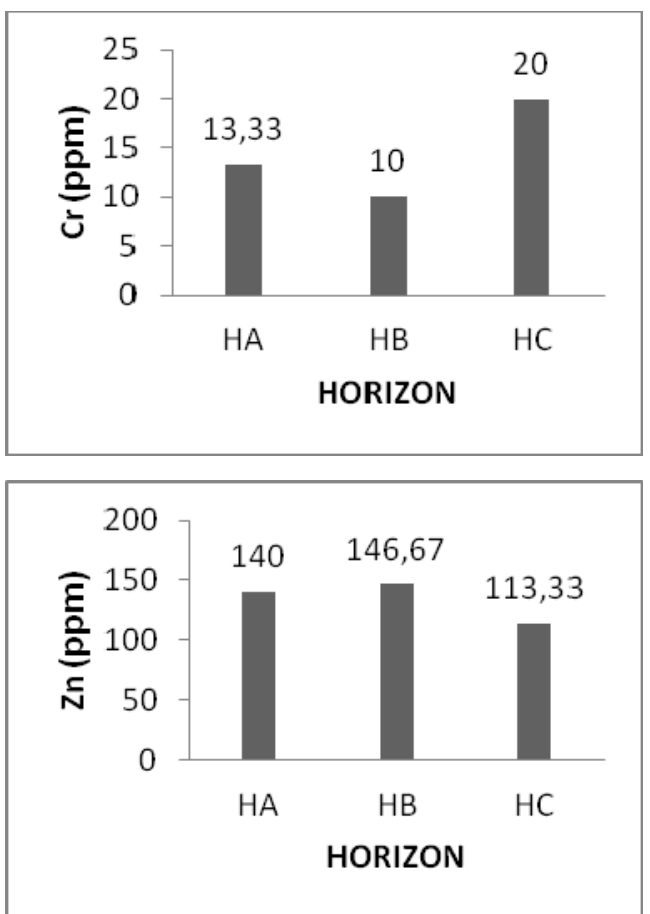
(Upper-Katanga Province, Democratic Republic of Congo)
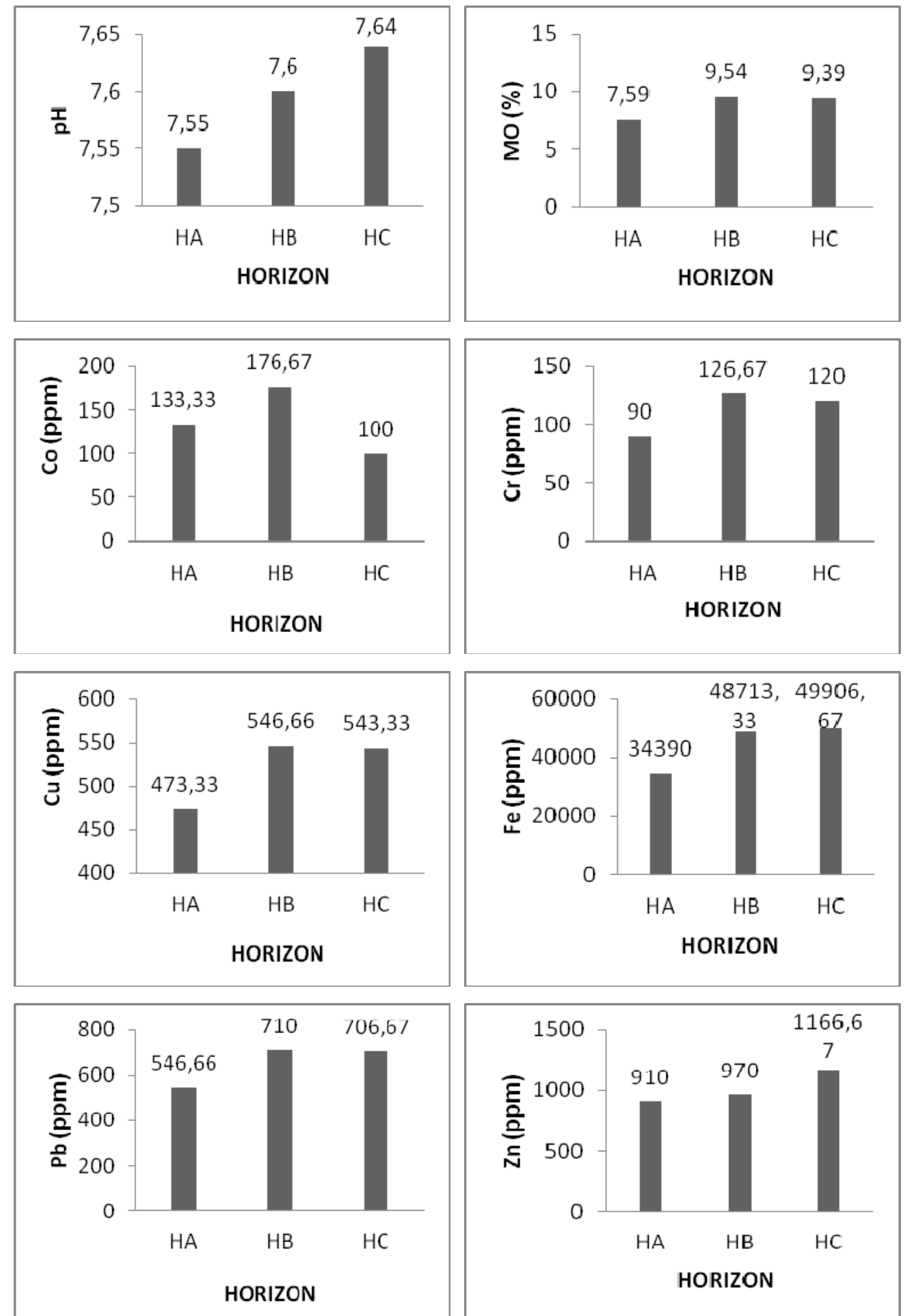

Fig. 3 Evolution of different parameter mean values in the SNB soil of North-eastern Lubumbashi during the period of February, March and April 2011 (rainy season). 
Assessment of Trace Metals in Soils of North-Eastern Lubumbashi

(Upper-Katanga Province, Democratic Republic of Congo)
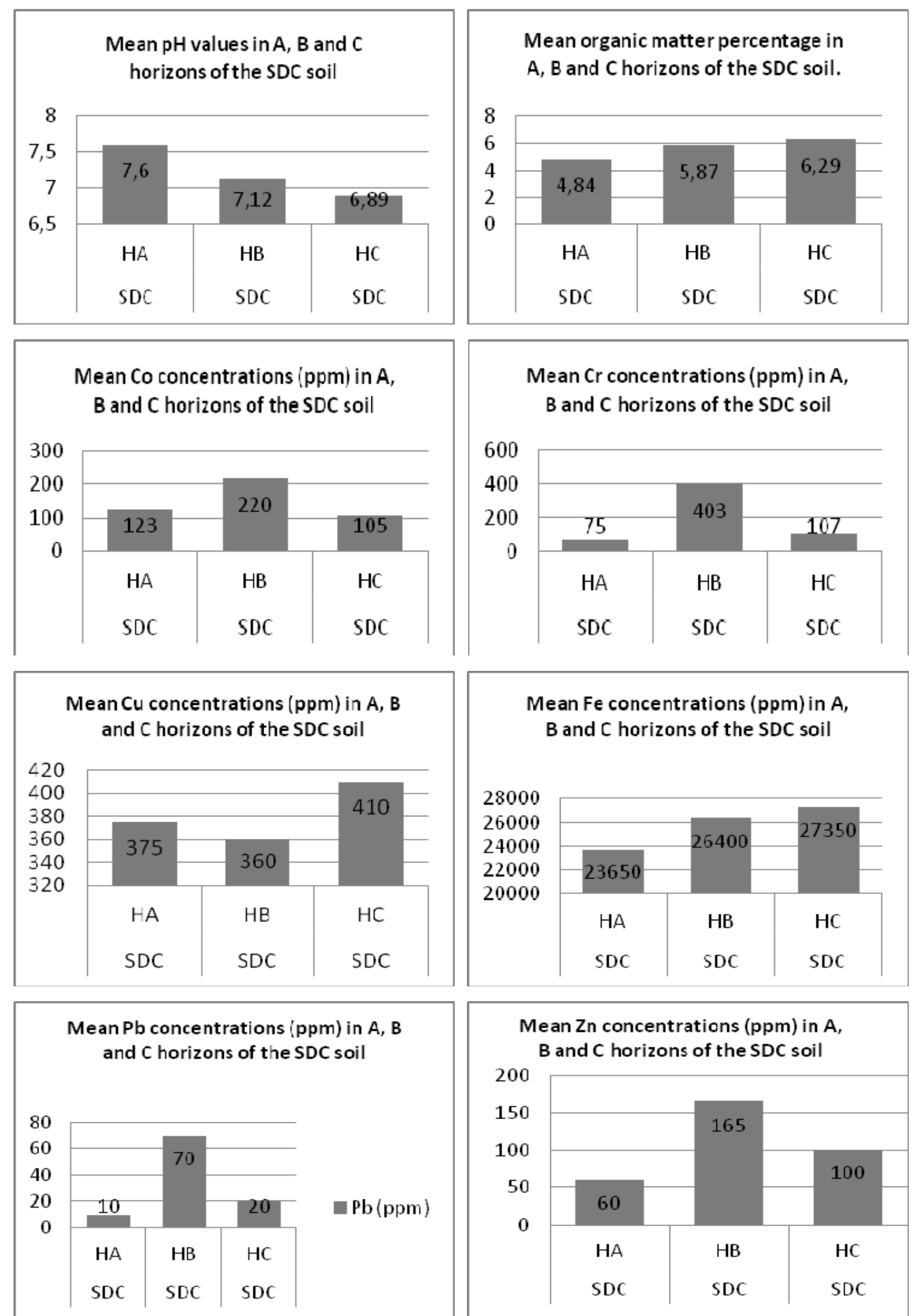

Fig. 4 Evolution of different parameter mean values in the SDC soil of North-eastern Lubumbashi during the period of May, June and July 2011 (dry season). 

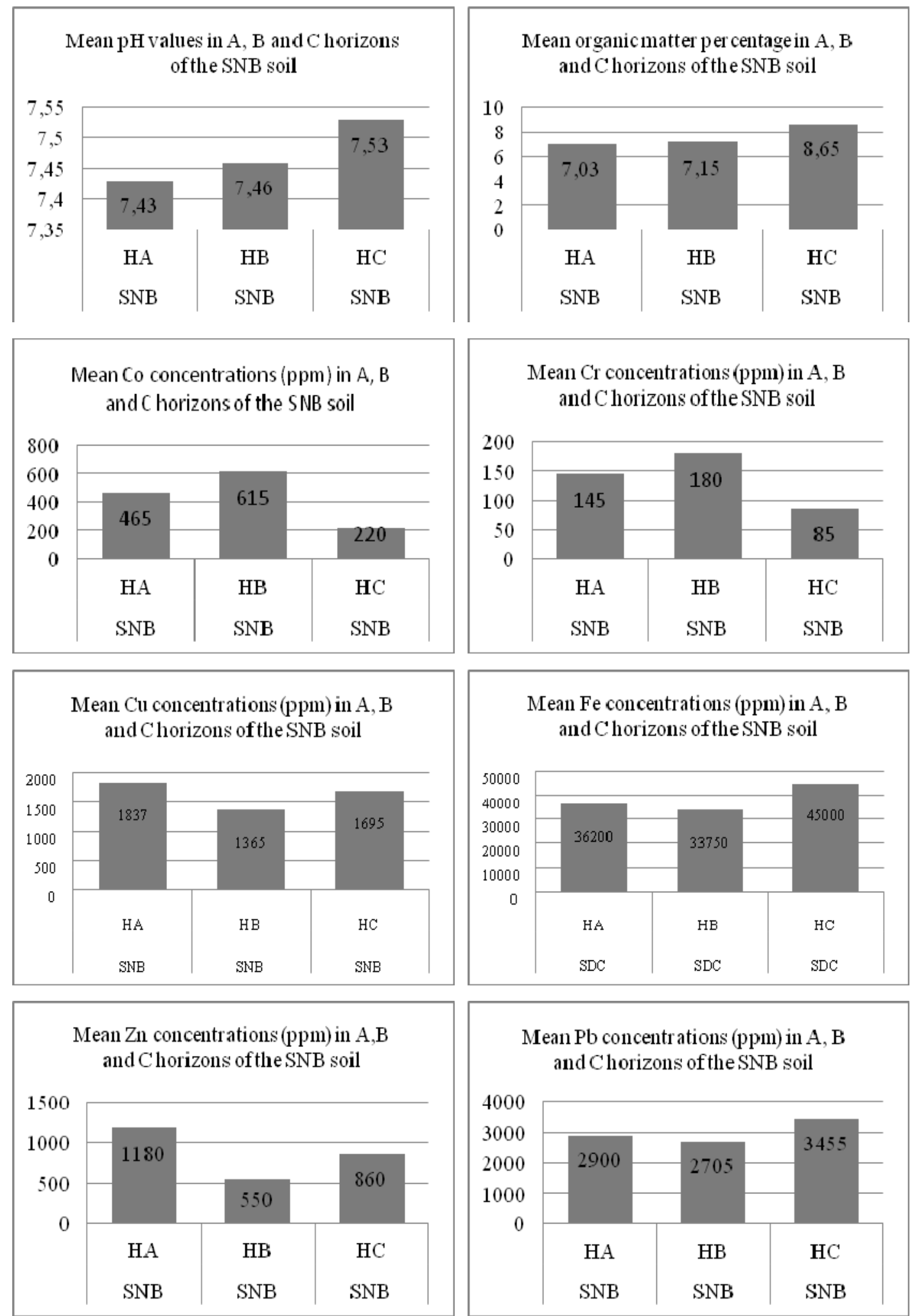

Fig. 5 Evolution of different parameter mean values in the SNB soil of North-eastern Lubumbashi during the period of May, June and July 2011 (dry season). 
Soil contamination origin evaluation was carried out using the vertical comparison method which consists in determining trace metal levels in function of the soil depth. If the gradient is oriented downward, that is an indication of trace metal contribution from natural origin. If the variation is in the other direction, one will think of anthropogenic origin.

\section{Conclusion}

This study carried out in the North-east of the Lubumbashi city from February to July 2011 showed that there were two soil types, the SNB black dump soil and the SDC Dembo soil, which may play the role of indicators of soil contamination by trace metals thus allowing to detect the impact of ore mining and processing in that area. The important organic matter content of those soils and their alkaline water-pH constitute a cause of essential demarcation in trace metals compared with the other studied soils. Thus the water brought by rain influences the values of $\mathrm{pH}$ and organic matter content which consequently change the trace metal levels in the profiles of those soils.

The SDC and SNB soils had higher levels of trace metals such as $\mathrm{Cu}, \mathrm{Co}, \mathrm{Fe}, \mathrm{Cr}, \mathrm{Pb}$ and $\mathrm{Zn}$ compared with the Swiss critical trace metal guidelines for agricultural soils. Those metals, throughout their anthropogenic origins, accumulate mostly in the $\mathrm{A}$ and B layers, except $\mathrm{Zn}$ in the SNB soil and $\mathrm{Cr}$ in the SDC soil which accumulate in the $\mathrm{C}$ horizon, suggesting a natural origin.

The SDC soil presents a high risk of $\mathrm{Pb}$ contamination especially as that soil offers a marshy character i.e. close to the groundwater table. Besides, it is the support of truck farming (market gardening) in that place which largely feeds with vegetable the population in the Lubumbashi city. Further studies covering a minimal period of twelve months will allow assessing eventual seasonal variations of trace metal levels of soils in the north-east of the Lubumbashi city.

\section{Acknowledgements}

Authors sincerely thank the personnel of the Robinson International in Africa laboratory in Lubumbashi, that of the laboratory of the Chemistry Department at Lubumbashi University and that of the Centre de Recherche Agro-Alimentaire (CRAA) for the analyses of authors' samples.

\section{References}

[1] Sirven, J. B. 2006. "Detection of Heavy Metals in Soils by Emission Spectroscopy with Laser Induced Plasma." Ph.D. thesis, Doctoral School of Physical Science and Engineering, University of Bordeaux.

[2] Shengo, I., and Mansoj, M. 2008. "The Pollution of the Surface Waters and Its Impact on the Quality of the Vegetables Cultivated and Consumed in the City of Lubumbashi." Environmental Health 8 (2): 58-67.

[3] Muhaya, B. B., Numbi, R. M., Lubala, F. T., Mugisho, J. B., and Tshibanda, D. K. 2015. "Heavy Metal Contamination of Well Water in the Kipushi m=Mining Town (Democratic Republic of Congo)." Journal of Environmental Science and Engineering B 4 (8): 403-418.

[4] Muhaya, B. B. M., Joiris, C. R., Leermakers, M., Deronde, L., Bossicart, M., and Baeyens, W. 1993. "Total Mercury and Methylmercury in Soils, Litter and Plants from the Zoniën (Soignes) Forest (Brussels, Belgium)." In Biological Indicators of Global Change, edited by Devos, P., Rammeloo, J. and Verstraeten, Ch. Brussels (Belgium).

[5] Muhaya, B. B. M., Leermakers, M., and Baeyens, W. 1997. "Total Mercury and Methylmercury in Sediments and in the Polychaete Nereis diversicolor at Groot Buitenschoor Scheldt Estuary, Belgium." Water, Air and Soil Pollution 94: 109-123.

[6] Baeyens, W., Meulemen, C., Muhaya, B., Leermakers, M. 1998. "Behaviour and Speciation of Mercury in the Scheldt Estuary (Water, Sediments and Benthic Organisms)." Hydrobiologia 366: 63-79.

[7] Mulowayi, W. N. 2001. "Contribution to the Demetallization of Hydrocarbon Pxidation Products by Acid Reagents." Annals of the Faculty of Science, UNILU 8: $142-146$.

[8] Kouamé, I. K., Gone, D. L., Savane, I., Kouassi E. A., Koffi, K., Goula, B. T. A, et al. 2006. "Relative Mobility of Heavy Metals from the Akouedo Dumping and Risk of Contamination of the Continental Terminal Groundwater (Abidjan - Ivory Coast)." Africa Science 2 (1): 39-56. 
[9] Violante, A., Cozzolino, V., Perelomov, L., Caporale, A. G., and Pigna, M. 2010. "Mobility and Bioavailability of Heavy Metals and Metalloids in Soil Environments." Journal of Soil Science and Plant Nutrition 10 (3): 268-292.

[10] Giasson, P., and Jaouich, A. 2008. "Soil Chemical Properties. Chapter 3." UQUAM, Hydrohane Technologies, Montreal p. 1-46.

[11] Mench, M., and Baize, D. 2004. "Contamination of Soils and our Food of Vegetal Origin by Trace Elements Assessed to Reduce Exposure." INERA's Letters of the Environment NR, 52.
[12] Deschamps, T., Benzaazoua, M., Bussiere, B., Belen T., and Mbonimpa, M. 2006. "Mechanisms of Heavy Metal Retention in Solid Phase: Case of the Stabilization of Contaminated Soils and Industrial Waste." The Electronic Review in Science of the Environment 7 (2): 1-11.

[13] Kao, T., El Mejahed, K., and Bouzidi, A. 2007. "Assessment of Metal Pollution in Agricultural Soils Irrigated with Sewage from the Town of Settat (Morocco)." Bulletin of the Scientific Institute, Rabat, Life Science Section 29: 89-92.

[14] Ramade, F. 2005. Elements of Ecology -Applied Ecology. 6th Edition Paris: Dunod. 